\title{
VARIATIONS IN MORPHOLOGY OF LUMBAR SPINAL CANAL IN DEGENERATIVE DISCOPATHY
}

\section{ZMIENNOŚĆ MORFOLOGII LEDŹWIOWEGO KANAŁU KRĘGOWEGO W CHOROBIE ZWYRODNIENIOWEJ KRĄŻKA}

\author{
Gustaw Wójcik $^{1(\mathrm{~A}, \mathrm{~B}, \mathrm{C}, \mathrm{D}, \mathrm{E}, \mathrm{F})}$, Agata Pocztarska ${ }^{2(\mathrm{D}, \mathrm{E}, \mathrm{F})}$
}

\author{
${ }^{1}$ Medical University of Lublin, Poland \\ ${ }^{2}$ Pope John Paul II State School of Higher Education in Biała Podlaska, Poland
}

Authors' contribution Wkład autorów: A. Study design/planning zaplanowanie badań B. Data collection/entry zebranie danych C. Data analysis/statistics dane - analiza i statystyki D. Data interpretation interpretacja danych E. Preparation of manuscript przygotowanie artykułu F. Literature analysis/search wyszukiwanie i analiza literatury G. Funds collection zebranie funduszy
Tables: 6

Figures: 0

References: 18

Submitted: 30.11 .2015

Accepted: 21.04.2016

\section{Summary}

Background. Lumbar spine, due to the large range of motion, is exposed to frequent occurrence of intervertebral disc disease. Discopathy initiates a series of changes as a result of a change in the morphology of the spinal canal. With age soft tissue undergoes degeneration as well as bone tissue, which favors the formation of the spinal canal stenosis. The aim of the study was to analyze and define the connections between the overload of intervertebral discs and changes in the volume of the spinal canal structures.

Material and methods. A group of 60 patients was examined using a multi-row helical CT scanner.

Results. Studies have shown that the shape of the spinal canal varies with age and reduces its capacity toward the sacral spine. There is the occurrence of three types of the spinal canal shape: oval, triangular and clover, which is the side effect of smoothing out of canal side pouches due to degenerative growth of zygapophysis.

Conclusions. Based on the analysis it was found that discopathy took place more often in the triangular canal, and less often in the clover-shaped canal, which indicates that the prevalence of discopaty may be related to the capacity of the spinal canal.

Keywords: Computer tomography, Spinal stenosis, Intervertebral disc displacement

\section{Streszczenie}

Wprowadzenie. Kręgosłup lędźwiowy ze względu na duży zakres ruchomości narażony jest na częste występowanie choroby krążka międzykręgowego. Dyskopatia zapoczątkowuje szereg zmian, w wyniku których zmienia się morfologia kanału kręgowego. Wraz z wiekiem zwyrodnieniu ulegają tkanki miękkie oraz tkanka kostna, co sprzyja powstawaniu stenozy kanału kręgowego.

Celem pracy było dokonanie analizy i określenie związków pomiędzy przeciążeniem krążków międzykręgowych, a zmianami objętościowymi struktur kanału kręgowego.

Materiał i metody. Przebadano grupę 60 pacjentów z wykorzystaniem wielorzędowego spiralnego tomografu komputerowego.

Wyniki. W badaniach wykazano, że kształt kanału kręgowego zmienia się wraz z wiekiem, a także zmniejsza swoją pojemność w kierunku odcinka krzyżowego. Stwierdzono występowanie trzech rodzajów kształtu kanału kręgowego: owalny, trójkątny oraz koniczyny, będącego efektem spłycenia zachyłków bocznych kanału z powodu zwyrodnieniowego rozrostu wyrostków stawowych.

Wnioski. Na podstawie analiz stwierdzono, że dyskopatia częściej miała miejsce w kanale o kształcie trójkątnym, a najrzadziej w kanale o kształcie koniczyny, co wskazuje na to, iż częstość występowania dyskopatii może mieć związek z pojemnością kanału kręgowego.

Słowa kluczowe: tomografia komputerowa, stenoza kanału kręgowego, dyskopatia

\section{Introduction}

Changes in the structure of the intervertebral discs are the cause of instability in the individual movement segments of the spine, which greatly reduces the physical fitness of patients. Overloading of intervertebral disc associated with a reduction of its height causes relaxation of the ligaments stabilizing the segment and is followed by fibrous ring bulge beyond the edges of the vertebral bodies. Occurring conditions allow migration of the nucleus pulposus towards the back or posterior side. The resulting protuberance exerts considerable pressure on the nerve tissue in the spinal canal as well as intervertebral holes resulting in formation of a canal stenosis. Damage to the spinal discs is the beginning of changes which are important for secondary reconstruction of the spinal canal Wojcik G, Pocztarska A. Variations in morphology of lumbar spinal canal in degenerative discopathy. Health Problems of Civilization. 2016; 10(4): 47-53. doi: $10.5114 / \mathrm{hpc} .2016 .63571$.

Address for correspondence / Adres korespondencyjny: Gustaw Wójcik, Medical University of Lublin, Chodźki 6, 20-093 Lublin, Poland, e-mail: gustaww@tlen. pl, phone: +48 817187503

Copyright: (C) 2016 Pope John Paul II State School of Higher Education in Biała Podlaska, Gustaw Wójcik, Agata Pocztarska. This is an Open Access journal, all articles are distributed under the terms of the Creative Commons Attribution-NonCommercial-ShareAlike 4.0 International (CC BY-NC-SA 4.0) License (http://creativecommons.org/licenses/by-nc-sa/4.0/), allowing third parties to copy and redistribute the material in any medium or format and to remix, transform, and build upon the material, provided the original work is properly cited and states its license. 
architecture. The relation of ntervertebral disc damage with consequential changes in intervertebral joints is not in doubt, but it is not known correlation between morphological changes in the spinal canal and the incidence of damaged intervertebral discs is not known. The studies attempt to analyze cases as to establish the relationship between the occurrence of intervertebral disc protuberance and sizes determining the capacity of the spinal canal, as well as the circumstances conducive to the formation of the lumbar spinal canal stenosis.

\section{Aim of work}

The aim of the study was to measure the spinal canal in the frontal and sagittal plane and to measure the surface area of the spinal canal and reference obtained data to assess the incidence of discopathy in the lumbar spine.

\section{Material and method}

The study population included 60 patients who were divided according to age and gender. The study group comprised 30 women and 30 men. The study was conducted based on analyzes of the results of patients in three age groups: young people, middle-aged and elderly, in whom, based on computed tomography, protuberance of the intervertebral disc in the lumbar spine was found. Although the mechanism leading to the intervertebral disc protuberance is different in young people and in the elderly, the focuse was on radiological symptom which is bulging of intervertebral disc beyond the edges of adjacent vertebral bodies, and the term discopathy is used to name the both cases.

The group of young people ranged between 18 and 34 years of age. The group of middle aged people ranged between 35 and 50 years old, and the group of older people ranged from 51 to 65 years old. Patients who previously had undergone no treatment of the lumbar spine were qualified for the study.

Data acquisition used a 16-row CT scanner. Carestream diagnostic station was used for the study analysis through which the extent of the changes was measured. Linear measurements of the spinal canal in the frontal and sagittal plane were made at the $1 / 3$ of the height of the vertebral bodies, where the base of the vertebral arches is the most massive. Linear parameters were evaluated between the arcs bases of discs as well as diameter in the anterior-posterior dimension in the sagittal plane of spinal canal its shape and surface area.

The dependence of the occurrence of discopathy on body mass index (BMI) was also examined.

CT scan was performed under the diagnosis of patients with pain in lumbar-sacral spine. All patients gave their consent to carry out this diagnostic test.

\section{Results}

In all cases of the failure of the intervertebral disc forming protuberance towards the back or posterior side modeling the dural sac and nerve root occurred. Dural sac is modeled not only by the raised intervertebral disc but also by the yellow ligament closing the spinal canal from the rear which tend to thicken in subsequent mechanism after the disc damage. The consequence of this conflict was the flattening of the contents of the spinal canal and shallowing of lumbar lordosis as a symptom of defense for reducing compression of nerve tissue and reducing the pain.

Table 1 shows the incidence of lumbar discopathy divided into single and multi-level for both sexes.

Table 1. The incidence of lumbar discopathy at different levels (hernia dominant)

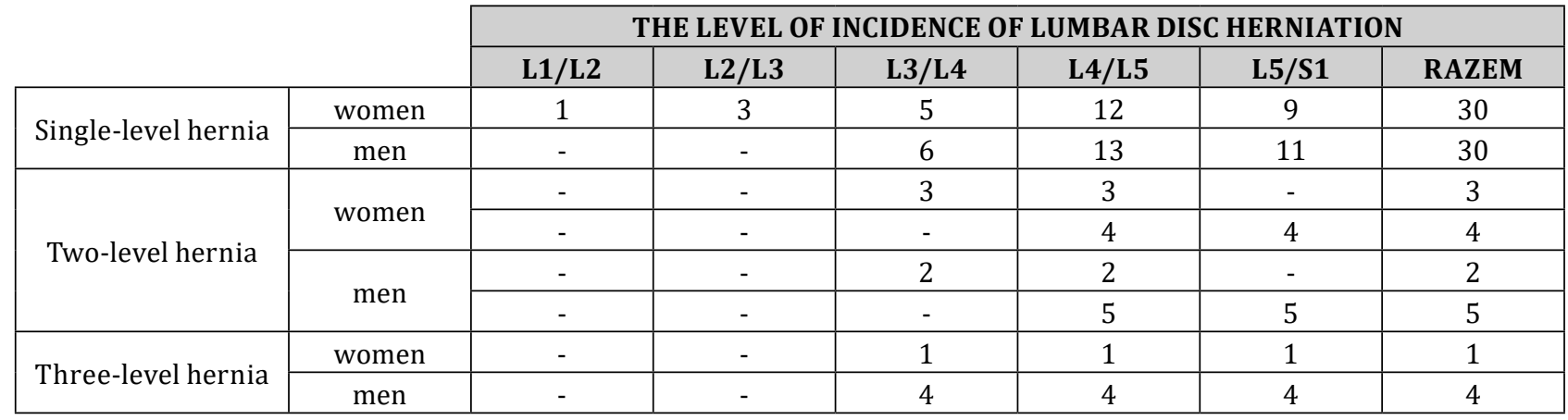


The destruction of the disc due to the reduction of its height, and stressing the annulus fibrosus into the spinal canal occurred most frequently at the height of the intervertebral space L3 / L4, L4 / L5 and L5 / S1. Based on the study multilevel damage was found. In 14 cases, the presence of two parallel protuberances in adjacent segments of the motor were observed, and in 5 cases they were seen at three levels at the same time however, one was always dominant. In 41 cases protuberances occurred individually.

Due to the shape of the canal cross section three basic types were identified: round, triangular, and clover. The surface area of the canal cross section from L3 to L5 corresponded to two basic shapes: triangular and clover, wherein the second was due to severe degenerative changes in the intervertebral joints. Degenerative changes taking place in the intervertebral joints cause their growth in all possible directions. Expansion of degenerative changes in the spinal canal causes shortness side pouches and thus reduces the capacity of the spinal canal.

In the studied group of women it was concluded that discopathy is more frequent in the triangular spinal canal triangular but the protuberance was on average of $0.6 \mathrm{~mm}$ of less value than in the spinal canal in the shape of a clover. In men discopathy more often occured in the clover-shaped canal, and protuberances with a higher value of intervertebral discs were observed in the canal of triangular cross-section.

Table 2. Frequency and size of occurrence of the protuberance of the intervertebral disk depending on the shape of the spinal canal.

\begin{tabular}{|c|c|c|c|c|c|}
\hline \multirow[b]{3}{*}{ gender } & \multirow[b]{3}{*}{ age } & \multicolumn{4}{|c|}{ OCCURRENCE OF DISCOPATHY DEPENDING ON THE SHAPE OF CANAL } \\
\hline & & \multicolumn{2}{|c|}{ CLOVER } & \multicolumn{2}{|c|}{ TRIANGLE } \\
\hline & & number of cases & $\begin{array}{c}\text { size of protube- } \\
\text { rance }(\mathrm{mm})\end{array}$ & number of cases & $\begin{array}{c}\text { size of protube- } \\
\text { rance }(\mathrm{mm})\end{array}$ \\
\hline \multirow{3}{*}{ WOMEN } & YOUNG & 3 & 5.86 & 7 & 5.34 \\
\hline & MIDDLE-AGED & 3 & 6.16 & 7 & 6.00 \\
\hline & ELDERLY & 4 & 6.95 & 6 & 6.18 \\
\hline \multirow{3}{*}{ MEN } & YOUNG & 4 & 6.72 & 6 & 7.06 \\
\hline & MIDDLE-AGED & 5 & 7.02 & 5 & 5.54 \\
\hline & ELDERLY & 8 & 5.60 & 2 & 7.75 \\
\hline \multicolumn{2}{|c|}{ Together } & $27(45 \%)$ & 6.38 & $33(55 \%)$ & 6.31 \\
\hline
\end{tabular}

Regardless of gender and age, discopathies were more frequent in the canals in the shape of a triangle. This difference accounted for $10 \%$. In contrast, the average size of protuberance of intervertebral disc was slightly higher in the canal in the shape of clover and was $6,38 \mathrm{~mm}$.

Table 3. Average size of the intervertebral disk protuberance depending on the shape of the canal depending on gender.

\begin{tabular}{|c|c|c|c|c|}
\cline { 2 - 5 } \multicolumn{1}{c|}{} & \multicolumn{2}{c|}{ Women } & clover & triangle \\
\cline { 2 - 5 } & clover & triangle & 6.72 & 7.06 \\
\hline YOUNG & 5.86 & 5.34 & 7.02 & 5.54 \\
\hline MIDDLE-AGED & 6.16 & 6.00 & 5.6 & 7.75 \\
\hline ELDERLY & 6.95 & 6.18 & 6.64 & 6.78 \\
\hline Together & 6.36 & 5.84 & & \\
\hline
\end{tabular}

In young women protuberance sagittal diameter is the smallest size but with age it has been gradually increasing. Discopathies of a higher value of protuberance are more frequent in the spinal canal in the shape of a clover.

For men, degenerative changes of zygapophysis are slightly larger and shallow side pouches thus reducing the volume of the spinal canal reserve. Thus dependence observed in men is opposite to that in women. The clover-shaped canals sagittal diameter hernia is getting smaller with age. Canals in the shape of a triangle predispose with age to the creation of protuberances of a larger size. 
Table 4. Incidence of discopathy in the age groups of women depending on the BMI

\begin{tabular}{|c|c|c|c|c|c|}
\cline { 2 - 6 } \multicolumn{1}{c|}{} & \multicolumn{4}{c|}{ NUMBER OF DISCOPATHIES IN AGE GROUPS OF WOMEN DEPENDING ON BMI } \\
\hline BMI & young & middle-aged & elderly & together & \% \\
\hline$<18,5$ & - & 1 & - & 1 & 3.3 \\
\hline $18,5-24,9$ & 8 & 4 & 2 & 14 & 46.6 \\
\hline $25,0-29,9$ & 2 & 3 & 1 & 6 & 20.0 \\
\hline $30,0-34,9$ & - & 2 & 4 & 3 & 20.0 \\
\hline $35,0-39,9$ & - & - & 3 & - & 10.0 \\
\hline$>40$ & - & - & - & & - \\
\hline
\end{tabular}

In the studied group of women most of the intervertebral disc damage (46\%) were found in patients with a BMI corresponding to the correct weight. Far less often discopathy concerned overweight women. This group accounted for $1 / 5$ of the surveyed women. In obesity of the first and second degree a total of $30 \%$ of the protuberance was found in the studied group of patients.

Table 5. Incidence of discopathy in the age groups of men depending on the BMI

\begin{tabular}{|c|c|c|c|c|c|}
\cline { 2 - 6 } \multicolumn{1}{c|}{} & \multicolumn{3}{c|}{ NUMBER OF DISCOPATHIES IN AGE GROUPS OF MEN DEPENDING ON BMI } \\
\hline BMI & young & middle-aged & elderly & together & \% \\
\hline$<18,5$ & - & - & - & - & - \\
\hline $18,5-24,9$ & 4 & 3 & 4 & 11 & 36.6 \\
\hline $25,0-29,9$ & 4 & 4 & 4 & 6 & 40.0 \\
\hline $30,0-34,9$ & 2 & 2 & 2 & 1 & 20.0 \\
\hline $35,0-39,9$ & - & 1 & - & - & 3.3 \\
\hline$>40$ & - & - & - & & - \\
\hline
\end{tabular}

In the studied group of men most of the intervertebral disc damage (40\%) had a BMI corresponding to overweight. In the group of patients with a BMI corresponding to normal weight the number of discopathies was slightly lower (36.6\%). In patients with varying degrees of obesity $23.3 \%$ of the intervertebral disc damage associated with the reduction of its height and rear protuberance was found.

Table 6. Average values of the spinal canal measurements in men and women

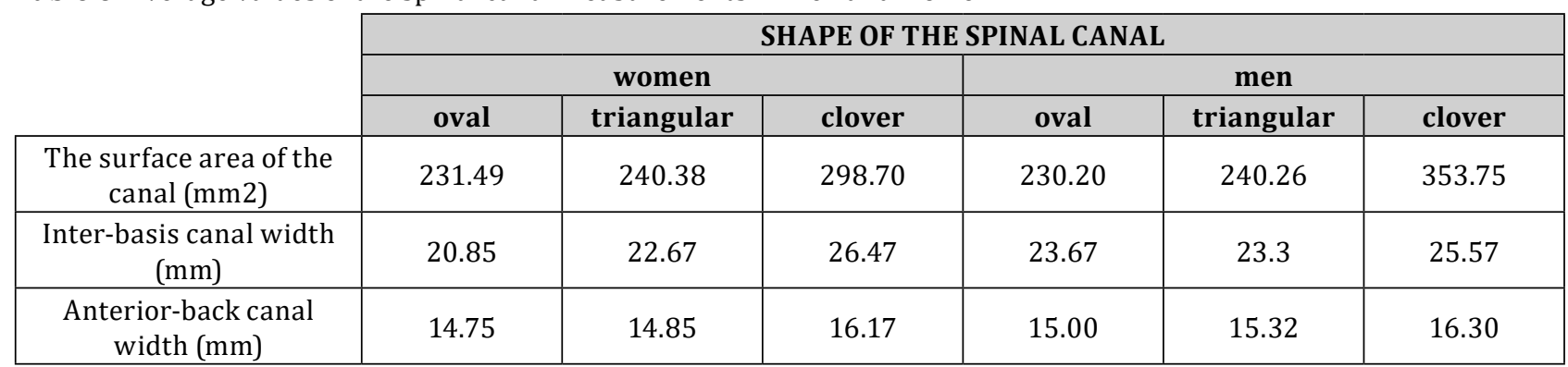

The gradual increase in surface area of the lumbar spinal canal from the level L1 to L5 occurs in both sexes. Degenerative changes of bone structures affect the reduction of the capacity of the spinal canal but not enough to cause the proportional inverse. The volume of the spinal canal side despite the shortness of pouches is the largest in the lower part of the spine. The linear width of the canal measured between the vertebral arches basis also increases in the distal direction as the width of the anterioposterior measured in the sagittal plane. Linear measurements of the width of the spinal canal are smaller in women than in men in the same age group.

\section{Discussion}

Computed tomography of the spine and spinal canal has already achieved a permanent place among diagnostic methods improving differential diagnosis in many processes including the spinal canal morphology [1].

Stenosis of the lumbar spine was first described in 1954 by Verbiest [2]. Spinal stenosis is associated with the occurrence of neural symptoms from spinal nerve roots and cauda equina fibers. Most often the narrowing of the spinal canal is predisposed by disc degeneration, a degenerative disease of the articular surfaces and the yellow ligament hypertrophy [2,3]. 
The biomechanics of the spine is closely connected with the terms of anatomical structures belonging to the axial movement organs. Harrison et al. [4] in their clinical observations indicate that the spine is subject to a permanent job, with the exception of sleep, during which there is a continuous change in capacitance of the spinal canal. These changes are possible to capture after a preliminary analysis aimed at capturing defects of posture. Postural disorders in turn result in changes in capacitance of the spinal canal, getting longer in time may cause deformation of the spinal canal. It follows that the space within the spinal canal and intervertebral canals is dependent on the body posture [5].

Typically, discopathic changes are accompanied by reflex shallowness of physiological curvature of the spine, which causes a slight increase in the diameter of the channel and the separation of adjacent vertebral lamina border. In contrast, increasing the curvature reduces the diameter of the channel and its volume, which essentially translates into a flattening of the dural sac in the sagittal plane. The shallowness or the aggravation of lumbar lordosis forces the displacement of nucleus pulposus, which further affects the modeling of abdominal structures of dural sac by intervertebral discs. The lateral flexion of the spine cause changes of the intervertebral canals capacity affecting the improvement of working conditions of nerve roots after the convex side of the curvature [4].

The studies of lumbar spinal canal to determine the precise geometric and morphology dimensions are important for spinal surgery and use of orthopedic instrumentation. Aly and Amin [6] studied 300 patients with pains in the lower back, using CT for imaging and evaluation of the morphology of the spinal canal. The researchers found out that the shape of the spinal canal of the lumbar is not uniform and is characterized by variability of waveform from a circular or oval in its upper part to the triangular in lower. The authors found out that the incidence of vertebral canal clover shape is associated with degeneration of the intervertebral disc, and the occurrence of degenerative changes in the intervertebral joints, and concerns mainly the vertebrae L4 and L5.

The gradual decline in channel capacity of the spine from the level L1 to L5 occurs in both sexes, but the linear measurement of the width of the channel is smaller in women than in men in the same age group [7].

With age, the intervertebral spaces are subject to aging and narrow, which results in a bulge of the annulus fibrosus. Most of those changes occur at the L3 / L4 and below. In contrast the narrowing of the spinal canal due to intervertebral joints followed by conversion usually occurs at the height of the segments L3 / L4 and L4 / L5 [8].

Changes in diameter of the spinal canal are an expression of the pathology leading to neuromuscular disorders which is why the spinal canal morphology assessment is an important diagnostic procedure [9].

Transverse dimension (inter-basis) of the spinal canal in the lumbar region is considered normal if it is less than $20 \mathrm{~mm}$, while the sagittal diameter (anterior-posterior) should not be less than $15 \mathrm{~mm}$ [9].

Tacar et al. [9] making anthropometric measurements of the lumbar spine in Turkish population found that for men the linear dimensions of the spinal canal are up to $1.5 \mathrm{~mm}$ larger than for women. Analyzing the ratio of the inter-basis dimension of the spinal canal to its length in the sagittal plane they stated the ratio to be between $0.55-0.60 \mathrm{~mm}$ in both sexes.

Korean scientists studied the lumbar spine linear relationships in the population of the Far East and stated that the average value of the diameter of the spinal canal of Korean population is smaller than that of the population of white and black races [10].

There were cstudies whose authors show that there are ethnic differences in linear dimensions and volume of the spinal canal, while the shape of the canal and degenerative changes in the lumbar spine have an identical course in all communities [11].

Kornberg and Rechtine [12] investigated the relationship between the linear dimensions of the spinal canal with the presence of disc disease and evaluated the effectiveness of treatments of discectomy at the level of the intervertebral space L4 / L5. The authors concluded that patients whose inter-basis width of spinal canal was less than $25 \mathrm{~mm}$ and a sagittal plan view of the spinal canal had a smaller dimension than $16 \mathrm{~mm}$ failed to obtain the expected improvement after surgery.

Sipola et al. [13] found, on the basis of tests carried out using magnetic resonance, that the narrowing of intervertebral holes in the course of lumbar spine has etiology common with the root symptoms.

Morita et al. [14] performed a retrospective case-control study aimed to examine the differences between the number of levels for the treatment of decompression and lumbar spinal canal stenosis. Imaging studies used for analysis are myelography of computed tomography and magnetic resonance imaging. The number of levels selected for the treatment of decompression in accordance with the result of myelography CT was significantly higher than in MRI. The coefficients of reliability and repeatability were higher for myelography CT than MRI which is of vital importance in the preoperative evaluation of the spinal canal stenosis.

Computed tomography and magnetic resonance imaging are excellent tools for diagnosing lumbar spine, thanks to which one can image the anatomy of the skeletal and soft structures of spinal canal and intervertebral holes [15]. 
French researchers Malghe et al. compared the accuracy of measuring the diameter of the spinal canal in the anterior-posterior axis projections at the height of L4 vertebra using computed tomography and magnetic resonance imaging. The results showed that linear measurements made in the same patients were lower up to $1.4 \mathrm{~mm}$ in the magnetic resonance than in computed tomography, which proves the fact that preoperative spinal canal stenosis must be diagnosed based on computed tomography [16].

Functional changes of the spine in patients with stenosis of the spinal canal are usually caused by compression of the nerve roots. Domed disc has been recognized as a major cause of compression. Hansson et al. [17] evaluated the change in the size of the lumbar spinal canal in patients with discectomy and bold ligamentum flavum. The authors concluded that an overload of the lumbar spine can produce changes in the intervertebral discs but also in the yellow ligaments which, likewise, are bulging, and are actively involved in the pathogenesis of spinal canal stenosis causing stenosis of up to $50-85 \%$.

Morishita et al. [18] investigated the relationship between the spinal canal stenosis with neurogenic intermittent claudication. The genesis of neurogenic claudication results from the nerve root ischemia, but its cause may lie in the disturbed anatomical relations prevailing in the spinal canal. The authors intraoperatively measured pressure values in intervertebral discs using a micro-sensor arranged in the catheter tip. The pressure increase was challenged by passive movements of the lower limbs. Patients who demonstrated large changes in pressure between the bend and snap had significantly poor ability to walk. Patients who have experienced a two-level stenosis of the lumbar spine showed a much smaller change in pressure between the bend and snap than in patients with a single-level spinal canal stenosis. This study suggests that a greater effect on intermittent claudication may be caused by the dynamic loads than degenerative changes occurring due to the static mechanical stresses.

\section{Conclusions}

The highest amount of hernias (46.6\%) was observed in the group of young women whose BMI corresponded to the correct weight. This leads to the conclusion that the main reason for the occurrence of hernias of the nucleus pulposus is physical activity that at a young age is the greatest. Sudden movements, especially axial rotation movements cause the most damage to the intervertebral disc. One-third of surveyed women had a BMI corresponding to obesity, and thus increased body mass also has a significant effect on the damaged disc, but less than normal physical activity. With age, physical activity decreases, which favors the formation of obesity. Increased body mass acts destructively on the spinal discs of the lower spine causing their dehydration and relaxation of the fibrous ring.

1. The study allows the following conclusions:

2. Cross-sectional area of the spinal canal decreases with age.

3. The degenerative growth of zygapophysis reduces the capacity of spinal canal but does not prevent the formation of hernias of the nucleus pulposus.

4. The morphological changes of the spinal canal are the result of aging and do not play a significant role in the prevention of discopathy.

5. The optimum shape of the spinal canal in the lateral plane is oval or triangular one.

\section{References:}

1. Friedmann G, Promper C. CT examination of the spine and the spinal canal. European Journal of Radiology. 1982; 2(1): 60-65.

2. Miyamoto M, Genbum Y, Ito H. Diagnosis and treatment of lumbar spinal canal stenosis. Journal of Nippon Medical School. 2002; 69(6): 583-7.

3. Kosaka H, Sairyo K, Biyani A, Leaman D, Yeasting R, Higashino K, et al. Pathomechanism of loss of elasticity and hypertrophy of lumbar ligamentum flavum in elderly patients with lumbar spinal canal stenosis. Spine. 2007; 32(25): 2805-11.

4. Harrison DE, Cailliet R, Harrison DD, Troyanovich SJ, Harrison SO. A review of biomechanics of the central nervous system-Part I: spinal canal deformations resulting from changes in posture. Journal of Manipulative \& Physiological Therapeutics. 1999; 22(4): 227-34.

5. Willen J, Danielson B, Gaulitz A, Niklason T, Schonstrom N, Hansson T. Dynamic effects on the lumbar spinal canal: axially loaded CT-myelography and MRI in patients with sciatica and/or neurogenic claudication. Spine. 1997; 22(24): 2968-76.

6. Aly T, Amin 0. Geometrical dimensions and morphological study of the lumbar spinal canal in the normal Egyptian population. Orthopedics. 2013; 36(2): 229-234. 
7. Janjua MZ. Muhammad F. Measurements of the normal adult lumbar spinal canal. JPMA - Journal of the Pakistan Medical Association. 1989; 39(10): 264-8.

8. Yoshizaki K. Radiographic and myeloscintigraphic evaluation of normal aging changes in the lumbar spine and the relationship with lumbar spinal canal stenosis. Journal of the Japanese Orthopaedic Association. 1987; 61(7): 933-42.

9. Tacar 0, Demirant A, Nas K, Altindag O. Morphology of the lumbar spinal canal in normal adult Turks. Yonsei Medical Journal. 2003; 44(4): 679-85.

10. Lee HM, Kim NH, Kim HJ, Chung IH. Morphometric study of the lumbar spinal canal in the Korean population. Spine. 1995; 20(15): 1679-84.

11. Amonoo-Kuofi HS, Patel PJ, Fatani JA. Transverse diameter of the lumbar spinal canal in normal adult Saudis. Acta Anatomica. 1990; 137(2): 124-8.

12. Kornberg M, Rechtine GR. Quantitative assessment of the fifth lumbar spinal canal by computed tomography in symptomatic L4-L5 disc disease. Spine. 1985; 10(4): 328-30.

13. Sipola P, Leinonen V, Niemelainen R, Aalto T, Vanninen R, Manninen H, et al. Visual and quantitative assessment of lateral lumbar spinal canal stenosis with magnetic resonance imaging. Acta Radiologica. 2011; 52(9): 1024-31.

14. Morita M, Miyauchi A, Okuda S, Oda T, Iwasaki M. Comparison between MRI and myelography in lumbar spinal canal stenosis for the decision of levels of decompression surgery. Journal of Spinal Disorders \& Techniques. 2011; 24(1): 31-36.

15. Hasegawa T, An HS, Haughton VM. Imaging anatomy of the lateral lumbar spinal canal. Seminars in Ultrasound, CT \& MR. 1993; 14(6): 404-13.

16. Malghem J, Willems X, Vande Berg B, Robert A, Cosnard G, Lecouvet F. Comparison of lumbar spinal canal measurements on MRI and CT. Journal de Radiologie. 2009; 90(4): 493-497.

17. Hansson T, Suzuki N, Hebelka H, Gaulitz A. The narrowing of the lumbar spinal canal during loaded MRI: the effects of the disc and ligamentum flavum. European Spine Journal. 2009; 18(5): 679-686.

18. Morishita Y, Hida S, Naito M, Arimizu J, Takamori Y. Neurogenic intermittent claudication in lumbar spinal canal stenosis: the clinical relationship between the local pressure of the intervertebral foramen and the clinical findings in lumbar spinal canal stenosis. Journal of Spinal Disorders \& Techniques. 2009; 22(2):130-4. 